\title{
5-ASA Induces Mild Acute Pancreatitis. Case Report and Review of the Literature
}

\author{
Ágnes Meczker, Alexandra Mikó, Péter Hegyi
}

Institute for Translational

Medicine, University of Pécs, Medical School, Pécs, Hungary

\author{
Address for correspondence: \\ Péter Hegyi, MD, PhD, DSc, \\ Director, Centre for \\ Translational Medicine, \\ University of Pécs, Hungary, \\ hegyi2009@gmail.com
}

Received: 22.01.2018 Accepted: 29.03.2018

\begin{abstract}
5 -aminosalicylic acid has been reported to be able of inducing acute pancreatitis as an adverse reaction. However, in most case reports, rechallenge of the drug is missing; therefore, evidence is still needed to confirm its role in the clinical course of acute pancreatitis and its influence on the outcome. Here, we report a case of recurrent acute pancreatitis secondary to 5 -aminosalicylic acid, with positive unintentional rechallenge. A systematic search of the literature was performed and 42 cases from 35 articles were summarized concerning the clinical course of 5-aminosalicylic acid induced acute pancreatitis.
\end{abstract}

Key words: acute pancreatitis - 5-ASA - 5-aminosalicylic acid - rechallenge - drug-induced - adverse drug reaction - Crohn's disease.

Abbreviations: 5-ASA: 5-aminosalicylic acid; AP: acute pancreatitis; CRP: C-reactive protein; CMV: cytomegalovirus; HIV: human immunodeficiency virus; HHV: human herpes virus; ERCP: endoscopic retrograde cholangiopancreatography; DIAP: drug-induced acute pancreatitis; MRCP: magnetic resonance cholangiopancreatography; ADR: adverse drug reaction.

\section{INTRODUCTION}

5 -aminosalicylic acid (5ASA: mesalazine, mesalamine) is an aminosalicylate antiinflammatory drug considered safe and effective in treating inflammatory bowel disease. Frequent side effects are diarrhea, abdominal pain, nausea, vomiting, bloating, headache and allergic skin rash. Acute pancreatitis (AP) is listed as rare in occurrence but is potentially lethal in severity. Pentasa $^{\varpi}$ is an ethylcellulosecoated, granulated, timedependent, prolonged-release preparation manufactured for balanced absorption of the active component, 5-ASA. However, several cases have been published reporting $\mathrm{AP}$ as a consequence of the therapy with 5-ASA-derived drugs [1-5]. Here, we report a case of recurrent AP secondary to 5-ASA, proven with positive rechallenge and a systematic review of the literature in this topic. We strictly followed the CARE guideline recommendations [6] to ensure the highest quality.

\section{CASE REPORT}

A 31-year-old white female presented to the Emergency Department at the University of Pécs, Hungary, with vomiting and severe cramping abdominal pain located to the left kidney and radiating to the back and the epigastric region.

Her medical history revealed mitral valve prolapse, multiple episodes of pneumothorax, cured with an atypical apical pulmonary resection. The patient was non-smoker, consumed alcohol occasionally, and denied taking illicit drugs. She had known allergies to trimethoprim and lactose, and family history was significant for hypertonia in her father and multiple sclerosis in her mother.

Six weeks prior to this index admission, she was diagnosed with colonic Crohn's disease and started on granulated 5-ASA (Pentasa $^{\oplus}$ ) in a dose of $2000 \mathrm{mg}$ oral daily.

Two weeks prior to this admission she had been admitted for abdominal discomfort, bloating, persistent diarrhea and chest pain. An exacerbation of Crohn's disease was assumed. 5-ASA was temporarily discontinued and methylprednisolone was added to her treatment. Abdominal ultrasonography 
showed normal findings. Pneumotorax, pulmonary embolism and pneumonia were excluded. 5-ASA was reintroduced with a dose of $4000 \mathrm{mg}$ and she was discharged. Figure 1 presents a brief illustration of the clinical course.

On current presentation, her abdomen was tender on palpation. The serum pancreatic amylase $(295 \mathrm{U} / \mathrm{L}$, normal: 28-100 U/L), and lipase levels (1455 U/L, normal: <60 U/L) were elevated. The levels of inflammatory parameters were increased with a C-reactive protein (CRP) value of $16.60 \mathrm{mg} / \mathrm{L}$ (normal $<5 \mathrm{mg} / \mathrm{L}$ ) and a white blood cell count of 41,300 G/L (normal: 4000-10000 G/L). On abdominal ultrasound the pancreas had normal echogenicity and echostructure, there were no stones in the gall bladder and no dilation of the common bile duct. A moderate wall thickening was present throughout the colon as a manifestation of Crohn's disease.

Acute pancreatitis (AP) was diagnosed, and the patient was treated according to the evidence-based practice guidelines $[7,8]$. She was given intravenous hydration, early nasogastric tube feeding, intravenous drotaverine $(40 \mathrm{mg})$, tramadol (50 $\mathrm{mg}$ ) and metamizole (1000 $\mathrm{mg}$ ) for pain management, and ondansetron (4 mg) for nausea. 5-ASA was discontinued immediately. She was not aware of any AP episodes before. No calcifications were detected in the pancreatic tissue on ultrasound. The serological tests showed a previous infection with Epstein-Barr Virus and the effect of vaccination against mumps and rubeola; active infections with CMV, Varicella-zoster, HIV1 and 2, Hepatitis A, B, and C, HHV and Adenovirus were excluded. No pathogenic PRSS1 mutations were found on genetic testing for predisposing factors of pancreatitis. Her calcium and triglyceride serum levels were in the reference range. No signs of vascular disease were found. No recent trauma occurred, and no surgical interventions or ERCP was performed. Hence, the diagnosis was idiopathic AP.

Amylase and lipase levels began to drop immediately after starting the treatment and the epigastric pain subsided on day two. Amylase level dropped to normal (45 IU/L), and the levels of lipase and inflammatory parameters progressively decreased. Since the first episode of AP was considered as idiopathic, the re-administration of 5-ASA on day four with one $4000 \mathrm{mg}$ dose was performed as an unintentional rechallenge. At the same time, the diet of the patient was advanced to a reduced amount of nasogastric tube feeding combined with a small amount of solid food and liquid. Rechallenge resulted in recurrence of the epigastric pain after 8 hours and rapid elevation of pancreatic enzyme levels. The causal connection between the drug intake and AP was recognized, and drug-induced AP (DIAP) was diagnosed, the previous treatment was resumed and 5-ASA was permanently withdrawn. Repeat ultrasonography on day five was remarkable for a pancreas with slightly inhomogeneous, low echogenicity, consistent with acute inflammation (Fig. 2). On day seven, pain subsided, diet was advanced uneventfully, pancreatic enzyme levels dropped to nearly normal values, and the patient was discharged.

Both AP episodes were considered clinically mild, in spite of the marked increase in the leucocyte count, which we considered a consequence of the steroid therapy. The bedside index of severity in acute pancreatitis (BISAP) score at presentation was 1 [10].

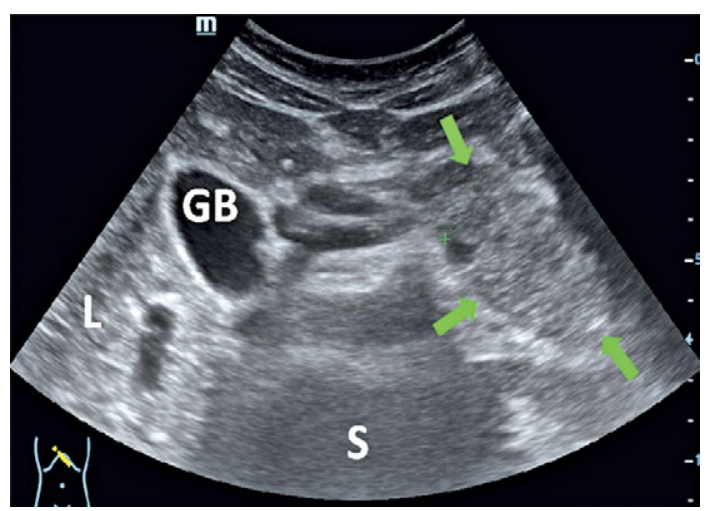

Fig. 2. Transabdominal ultrasonography one day after rechallenge with 5-ASA (06.08.2017): the pancreas (marked with arrows) is slightly inhomogeneous with low echogenicity, consistent with acute inflammation. $\mathrm{L}=$ liver, $\mathrm{GB}=$ gall bladder, $\mathrm{S}=$ spine.

\begin{tabular}{|c|}
\hline 20 June 2017 \\
\hline Diagnosed with Crohn's colitis, 5-ASA prescribed in a dose of $2000 \mathrm{mg}$ \\
\hline 2 \\
\hline 20 July 2017 \\
\hline Admitted with mediastinal pain, imaging examinations of the chest were negative, symptomatic treatment, 5 -ASA withdrawn \\
\hline 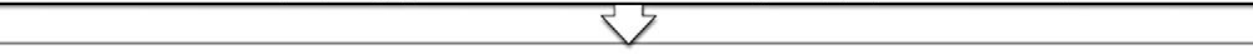 \\
\hline 24 July 2017 \\
\hline Discharged symptom-free, 5-ASA reintroduced in a dose of $4000 \mathrm{mg}$ for assumed exacerbation of Crohn's colitis \\
\hline$<$ \\
\hline 2 August 2017 \\
\hline Admitted with abdominal pain, nausea, vomiting, diagnosed with idiopathic AP, 5-ASA withdrawn \\
\hline 2 \\
\hline 5 August 2017 \\
\hline AP resolved, rechallenged with a single dose of $4000 \mathrm{mg}$ 5-ASA \\
\hline 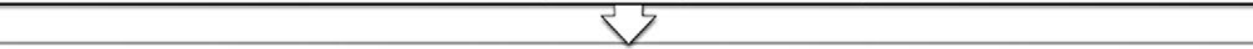 \\
\hline 6 August 2017 \\
\hline Relapse of acute pancreatitis, drug-induced AP was diagnosed, 5-ASA permanently discontinued \\
\hline 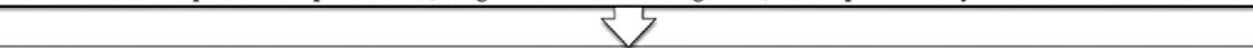 \\
\hline 8 August 2017 \\
\hline Discharged symptom-free \\
\hline
\end{tabular}

Fig. 1.Timeline of clinical course. 
At the three-month follow-up, the patient had no recurrence of pancreatitis. Her Crohn's colitis symptoms are currently managed with budesonide and azathioprine. Magnetic resonance enterography four weeks after admission disclosed no involvement of the small bowel in Crohn's disease. Abdominal ultrasonography and magnetic resonance cholangiopancreatography (MRCP) performed five weeks after admission disclosed normal findings.

\section{SYSTEMATIC REVIEW OF THE LITERATURE}

We performed a systematic literature search on April 2017 on the databases PubMed, EMBASE and Web of Science with the search terms "5-ASA AND pancreatitis" with limitations of English language and human target, regardless of the date of publication (Fig. 3). Studies were included only if authors concluded that 5-ASA-derived medication was the most probable cause of the adverse drug reaction (ADR), meeting only one diagnostic criteria for AP according to the IAP/APA evidence-based guidelines, such as asymptomatic pancreatic enzyme level increase or abdominal pain. Thirtyfive manuscripts, including 42 patients [1-5, 11-40] were identified applying this searching strategy (Table I). The ratio female/male was $24 / 19$. The mean age was $26.88 \pm 11.1$ years; 9 patients were pediatric cases (under 18 years of age). Most of the identified patients treated with 5-ASA derived drugs were suffering from ulcerative colitis $(67.4 \%, \mathrm{n}=29)$ and Crohn's disease $(23.3 \%, \mathrm{n}=10)$. One case of regional enteritis and one of unspecific colitis were found, and there was no data concerning the condition in two cases. Sulfasalazine was responsible in $35.7 \%(\mathrm{n}=30)$ for the ADRs. 5-ASA in $\mathrm{pH}$-dependent coating, in time-dependent coating and in otherwise non specified form caused ADRs in 22.6\% $(n=19), 8.3 \%(n=7)$ and $22.6 \%(n=19)$ of the identified cases. 5-ASA in enema form and Olsalazine were shown to cause ADRs in $11.9 \%(n=10)$ and $4.8 \%(n=4)$.

\section{DISCUSSION}

The most common etiologies for AP are gallstones, biliary sludge or microlithiasis, alcohol, smoking, hypertriglyceridemia, post-ERCP status, hypercalcemia, genetic mutations, infections or toxins, trauma, pancreas divisum and vascular disease $[41$, 42]. The rest of the episodes are usually termed idiopathic. Drug-induced AP is rare and challenging to identify because it has no clinical features to distinguish it from the more common etiologies of AP [43]. Moreover, because it is unethical to intentionally rechallenge with the offending drug due to the potentially life-threatening nature of pancreatitis, in most cases it remains a speculative diagnosis made by exclusion.

A classification of drugs reported to cause AP was made by Badalov et al. in 2007 [43], based on the published weight of evidence. Four classes of drugs were identified. Class Ia included drugs that previously had been described as positively rechallenged at least once, with all other etiologies ruled out. 5-ASA belonged to the class Ia category of drugs; nonetheless, cases with positive rechallenge and parallel exclusion of all other etiologies in the literature are still rare.

We analyzed the clinical course of 5-ASA-induced AP cases found on the systematic literature search. Hypersensitivity [ 1 , $2,11,15,37]$ and idiosyncrasy $[1,29]$ are usually thought to be involved in the pathogenic mechanism of 5-ASA-induced AP (according to $38.9 \%$ of the authors). In most of the identified cases, the reaction seemed not to be dose-dependent, however,

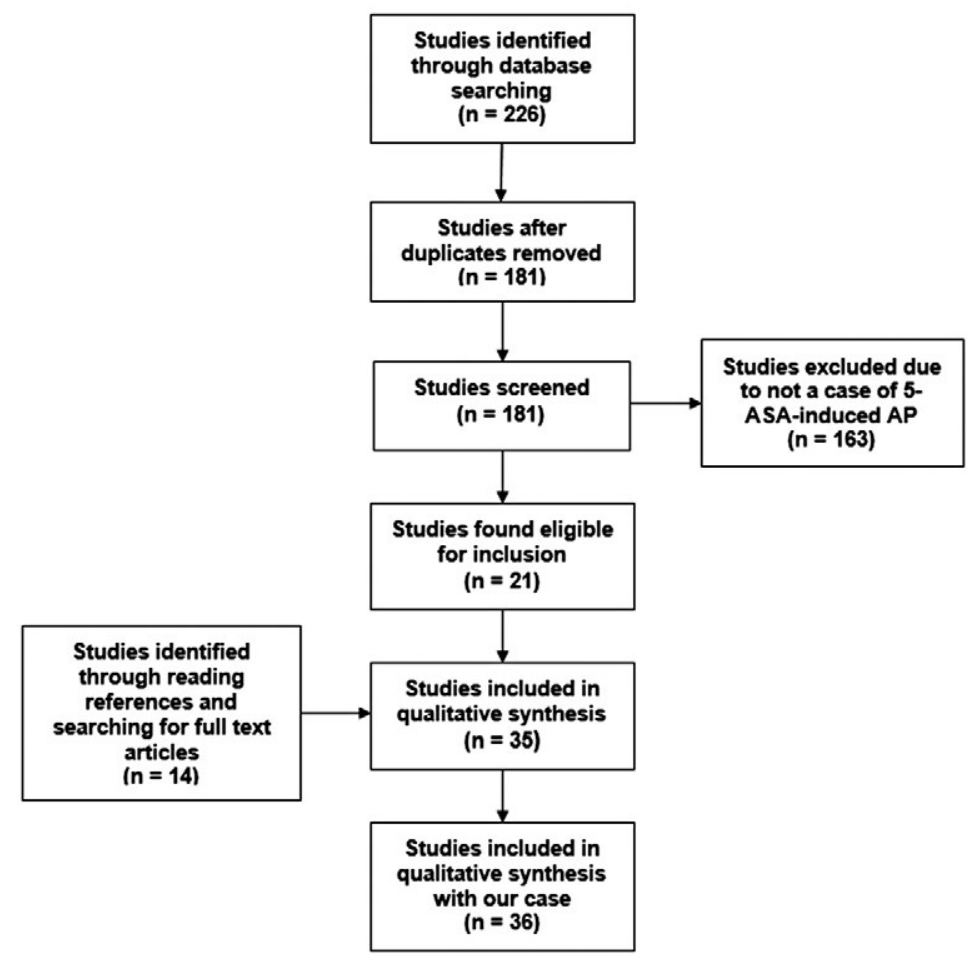

Fig. 3. Studies identified through systematic literature search 
Table II. Possible etiological factors for acute pancreatitis

\begin{tabular}{|c|c|c|c|}
\hline Possible etiologies & Patient history & Laboratory parameter or examination & Probable factor? \\
\hline Biliary & No history & $\begin{array}{l}\text { No gall stones. no biliary duct dilations on } \\
\text { ultrasonography }\end{array}$ & no \\
\hline Alcohol & Non-drinker & - & no \\
\hline Smoking & Non-smoker & - & no \\
\hline Hypertriglyceridemia & No history & $0.62 \mathrm{mmol} / \mathrm{L}$ (ref: $0.00-1.70$ ) & no \\
\hline Post-ERCP & No ERCP done & - & no \\
\hline Hypercalcemia & No history & $2.28 \mathrm{mmol} / \mathrm{L}$ (ref: $2.15-2.55)$ & no \\
\hline Genetic mutations & No family history & Negative for PRSS1 & no \\
\hline Infections, toxins & No history & $\begin{array}{l}\text { No active mumps, rubeola, EBV, CMV, Varicella-zoster, } \\
\text { HIV1 and 2, Hepatitis A, B, and C, HHV, Adenovirus }\end{array}$ & no \\
\hline Trauma & No history & - & no \\
\hline Pancreas divisum & No history & Excluded by MRCP & no \\
\hline Vascular disease & No history & - & no \\
\hline $\begin{array}{l}\text { Extraintestinal } \\
\text { manifestation of IBD }\end{array}$ & No history & Excluded by magnetic resonance enterography & no \\
\hline Drug & Treatment for IBD & - & yes \\
\hline
\end{tabular}

the specific underlying mechanism remained a matter for speculation. We found one report of assumed dose-dependent toxicity [12]. The latency between intake of 5-ASA and onset of pancreatitis usually varied between a few days and a few months, however, DIAP can occur after long term treatment as well $[4,12,21,28,35,39]$. The route of administration $[4,25,29$, 31,39 ] (either oral or rectal) and use of coated formulations [13,17 ] (time- or pH-dependent) did not appear to affect the risk of $\mathrm{AP}$, and in most of the cases, there was a rapid recurrence if rechallenged $[3,12,14,15,18] .5$-ASA induced AP was usually self-limited. In almost half (47.6\%) of the identified cases, there was no data concerning the imaging of the pancreas, and in $13.1 \%$, the imaging examinations showed normal findings. The severity of AP and length of hospitalization were mostly not described by the authors. In the cases which reported severity, AP was usually mild $(73.7 \%)[2,5,11,19,22,25,28,38]$, one moderately severe episode was found [31], and of the four severe cases reported [4, 20,32], two were lethal; $60.5 \%$ of the identified patients $(n=26)$ were rechallenged positively with one of the formulations of the 5-ASA. After discontinuation of the offending drug, symptoms usually disappeared quickly $[3,12,14,15,18]$, as observed in our case as well.

Our patient had no fever, no skin rash or peripheral eosinophilia, which would be suggestive of an allergic reaction: the pathogenic mechanism was probably an idiosyncratic reaction [44], but hypersensitivity cannot be excluded. At presentation, medications were: 5-ASA for 41 days, metoprolol for three years, methylprednisolone for 13 days, pantoprazole for two weeks and potassium-chloride intermittently. We ruled out potassium chloride as the offending drug because it had never been suspected as a cause of AP. Metoprolol cannot be ruled out totally because it was previously noted to cause AP [45] in the literature. Our patient took metoprolol for three years without adverse events and during her entire hospitalization, including the time of pancreatic enzyme level normalization and symptomatic improvement. Few cases reported pantoprazole $[46,47]$ and methylprednisolone [48-
54] induced AP, but in our patient, these drugs were continued throughout the hospital stay as well. Parallel to the rechallenge, our patient's diet was advanced, which could cause recurrence of AP. However, this is unlikely because repeated advancement two days later took place uneventfully.

Our patient's medical history strongly suggests that 5-ASA was the cause of her AP. We ruled out several other etiologies for AP (Table II). Our case therefore reached a score of 8 , probable causality on the Naranjo adverse drug reaction probability scale [55].

\section{CONCLUSION}

Rechallenging with a drug which can be a possible cause of $\mathrm{AP}$ is ethically questionable and is usually not done because of the danger of recurrence of a potentially severe disease. Intentional rechallenge can be reasonable in rare cases if the drug is the only therapy of a life-threatening disease and readministration is probably worth taking the risk. In our patient, the causal relationship between the drug intake and the first mild AP episode was not recognized first, and the patient was diagnosed with idiopathic AP; consequently, an unintentional positive rechallenge occurred, which has the biggest weight of evidence in assessing causality in the course of DIAP.

\section{Conflicts of interest: No conflict to declare.}

Authors' contributions: Á.M. conducted the acquisition of data and wrote the paper; Al.M. contributed to the acquisition and interpretation of data; P.H. made critical revisions to the manuscript on important intellectual content.

Acknowledgement: The study was supported by Project Grants (KH125678 to PH), the Economic Development and Innovation Operative Programme Grant (GINOP 2.3.2-15-2016-00048 to $\mathrm{PH}$ ) and Human Resources Development Operational Programme Grant (EFOP-3.6.2-16-2017-00006 to $\mathrm{PH}$ ) from the 
National Research, Development and Innovation Office, and by a Momentum Grant from the Hungarian Academy of Sciences (LP2014-10/2014 to PH).

We would like to thank Balázs Németh for the genetic testing, Nándor Faluhelyi for performing the MRCP examination, and Patrícia Sarlós and Szilárd Gódi for treating the patient to the best of their ability.

Supplementary material: To access the supplementary material visit the online version of the J Gastrointestin Liver Dis at http://dx.doi. org/10.15403/jgld.2014.1121.272.asa

\section{REFERENCES}

1. Abdullah AM, Scott RB, Martin SR. Acute pancreatitis secondary to 5 -aminosalicylic acid in a child with ulcerative colitis. J Pediatr Gastroenterol Nutr 1993;17:441-444.

2. Arai $\mathrm{Y}$, Arihiro $\mathrm{S}$, Ide $\mathrm{D}$, et al. Acute pancreatitis due to $\mathrm{pH}$-dependent mesalazine that occurred in the course of ulcerative colitis. Case Rep Gastroenterol 2011;5:610-616. doi:10.1159/000333605

3. Eto H, Kawabe K, Miyahara Y, et al. Drug-induced pancreatitis diagnosed by Mesalazine challenge test: Case report. J Gastroenterol Hepatol (Australia) 2016;31(Suppl 3):255. doi:10.1111/jgh.13540

4. Kutsenko A, Herzog K, Cohen M, Wan D, Bosworth B, Kahaleh M. A case of lialda ${ }^{\circ}$-induced pancreatitis. Am J Gastroenterol 2014;109:S295. doi:10.1038/ajg.2014.279

5. Paul AC, Oommen SP, Angami S, Moses PD. Acute pancreatitis in a child with idiopathic ulceative colitis on long-term 5-aminosalicylic acid therapy. Indian J Gastroenterol 2000;19:195-196

6. Gagnier JJ, Kienle G, Altman DG, Moher D, Sox H, Riley D. The CARE guidelines: consensus-based clinical case reporting guideline development. BMJ Case Rep 2013. doi:10.1136/bcr-2013-201554

7. Working Group IAP/APA Acute Pancreatitis Guidelines. IAP/APA evidence-based guidelines for the management of acute pancreatitis. Pancreatology 2013;13(4 Suppl 2):e1-e15. doi:10.1016/j.pan.2013.07.063

8. Hritz I, Czako L, Dubravcsik Z, et al. Acute pancreatitis. Evidence-based practice guidelines, prepared by the Hungarian Pancreatic Study Group Orv Hetil 2015;156:244-261. doi:10.1556/OH.2015.30059

9. Parniczky A, Kui B, Szentesi A, et al. Prospective, Multicentre, Nationwide Clinical Data from 600 Cases of Acute Pancreatitis. PLoS One 2016;110:e0165309. doi:10.1371/journal.pone.0165309

10. Wu BU, Johannes RS, Sun X, Tabak Y, Conwell DL, Banks PA. The early prediction of mortality in acute pancreatitis: a large population-based study. Gut 2008;57:1698-1703. doi:10.1136/gut.2008.152702

11. Adachi E, Okazaki K, Matsushima Y, et al. Acute pancreatitis secondary to 5-aminosalicylic acid therapy in a patient with ulcerative colitis. Int J Pancreatol 1999;25:217-221.

12. Al-Zayani J. Acute pancreatitis associated with the use of 5 -aminosaliclic acid and sulfasalazine in a patient with ulcerative colitis. J Bahrain Med Soc 1997;9:55-59.

13. Anderson JR, Johnston GW, Kennedy TL. Drug-Associated Recurrent Pancreatitis. Dig Surg 1985;2:24-26. doi:10.1159/000171666

14. Block MB, Genant HK, Kirsner JB. Pancreatitis as an adverse reaction to salicylazosulfapyridine. N Engl J Med 1970;282:380-382. doi:10.1056/ NEJM197002122820710

15. Chiba M, Horie $\mathrm{Y}$, Ishida H, Arakawa H, Masamune O. A case of salicylazosulfapyridine (Salazopyrin)- induced acute pancreatitis with positive lymphocyte stimulation test (LST). Gastroenterol Jpn 1987;22:228-233.
16. Daniel F, Seksik P, Cacheux W, Jian R, Marteau P. Tolerance of 4-aminosalicylic acid enemas in patients with inflammatory bowel disease and 5-aminosalicylic-induced acute pancreatitis. Inflamm Bowel Dis 2004;10:258-260. doi:10.1097/00054725-200405000-00013

17. Debongnie JC, Dekoninck X. Sulfasalazine, 5-ASA and acute pancreatitis in Crohn's disease. J Clin Gastroenterol 1994;19:348-349. doi:10.1097/00004836-199412000-00024

18. Deprez P, Descamps C, Fiasse R. Pancreatitis induced by 5 -aminosalicylic acid. Lancet 1989;2:445-446. doi:10.1016/S0140-6736(89)90620-X

19. Erdkamp F, Houben M, Ackerman E, Breed W, van Spreeuwel J. Pancreatitis induced by mesalamine. Neth J Med 1992;41:71-73.

20. Faintuch J, Mott CB, Machado MC. Pancreatitis and pancreatic necrosis during sulfasalazine therapy. Int Surg 1985;70:271-272.

21. Fernandez J, Sala M, Panes J, Feu F, Navarro S, Teres J. Acute pancreatitis after long-term 5-aminosalicylic acid therapy. Am J Gastroenterol 1997;92:2302-2303.

22. Fiorentini MT, Fracchia M, Galatola G, Barlotta A, de la Pierre M. Acute pancreatitis during oral 5-aminosalicylic acid therapy. Dig Dis Sci 1990;35:1180-1182. doi:10.1007/BF01537594

23. Garau P, Orenstein SR, Neigut DA, Kocoshis SA. Pancreatitis associated with olsalazine and sulfasalazine in children with ulcerative colitis. J Pediatr Gastroenterol Nutr 1994;18:481-485.

24. Inoue $\mathrm{H}$, Shiraki $\mathrm{K}$, Okano $\mathrm{H}$, et al. Acute pancreatitis in patients with ulcerative colitis. Dig Dis Sci 2005;50:1064-1067. doi:10.1007/s10620005-2705-7

25. Isaacs KL, Murphy D. Pancreatitis after rectal administration of 5-aminosalicylic acid. J Clin Gastroenterol 1990;12:198-199. doi:10.1097/00004836-199004000-00019

26. Manfredini R, Bariani L, Chierici F, et al. Acute pancreatitis associated with mesalamine: A case report and review of the literature. Adv Ther 1996;13:216-219.

27. Niu G, Zhang X. A case of drug-induced acute pancreatitis Pancreatology 2016;16:S46.

28. Ouakaa-Kchaou A, Gargouri D, Kochlef A, et al. Acute pancreatitis secondary to long-term 5-aminosalicylic acid therapy in a patient with ulcerative colitis: a case-report. Tunis Med 2014;92:423.

29. Paerregaard A, Krasilnikoff PA. Pancreatitis in a child after rectal administration of 5-aminosalicylic acid. Inflamm Bowel Dis 1997;3:2021. doi:10.1097/00054725-199703000-00004

30. Poldermans D, Van Blankenstein M. Pancreatitis induced by disodium azodisalicylate. Am J Gastroenterol 1988;83:578-580.

31. Radke M, Bartolomaeus G, Muller M, Richter I. Acute pancreatitis in Crohn's disease due to 5-ASA therapy. J Pediatr Gastroenterol Nutr 1993;16:337-339.

32. Rubin R. Sulfasalazine-induced fulminant hepatic failure and necrotizing pancreatitis. Am J Gastroenterol 1994;89:789-791.

33. Sachedina B, Saibil F, Cohen LB, Whittey J. Acute pancreatitis due to 5-aminosalicylate. Ann Intern Med 1989;110:490-492. doi:10.7326/0003-4819-110-6-490

34. Suryapranata $\mathrm{H}, \mathrm{De}$ Vries H. Pancreatitis associated with sulphasalazine. Br Med J 1986;292:732.

35. Toubanakis C, Batziou E, Sipsas N, Galanopoulos G, Tzivras M, Archimandritis A. Acute pancreatitis after long-term therapy with mesalazine, and hyperamylasaemia associated with azathioprine in a patient with ulcerative colitis. Eur J Gastroenterol Hepatol 2003;15:933-934.

36. Tran K, Froguel E, Jian R, Lemann M, Modigliani R. Acute pancreatitis induced by mesalazine. J Clin Gastroenterol 1991;13:715-716.

37. Din S, Pang QYL, Chakraborti E, Norton B. Two episodes of acute pancreatitis triggered by consecutive administration of 5-aminosalicylic 
acid and azathioprine therapy for Crohn's disease. Journal of Pharmacy and Clinical Sciences 2013;7:26-28.

38. Tanigawara $\mathrm{Y}$, Kita T, Aoyama N, et al. $\mathrm{N}$-acetyltransferase 2 genotyperelated sulfapyridine acetylation and its adverse events. Biol Pharm Bull 2002;25:1058-1062. doi:10.1248/bpb.25.1058

39. Uribarri-Gonzalez L, Barreiro-de Acosta M, Dominguez-Muñoz JE. Acute pancreatitis secondary to topical and oral treatment with mesalamine in a patient with ulcerative colitis. Int J Hepatobiliary Pancreat Dis 2016;6:64-67.

40. Wada S, Kumagai H, Yokoyama K, et al. Mesalazine allergy in a boy with ulcerative colitis: clinical usefulness of mucosal biopsy criteria. Clin J Gastroenterol 2016;9:302-305. doi:10.1007/s12328-016-0675-2

41. Eland IA, van Puijenbroek EP, Sturkenboom MJ, Wilson JH, Stricker BH. Drug-associated acute pancreatitis: twenty-one years of spontaneous reporting in The Netherlands. Am J Gastroenterol 1999;94:2417-2422. doi:10.1111/j.1572-0241.1999.01367.x

42. Lankisch PG, Apte M, Banks PA. Acute pancreatitis. Lancet 2015;386:8596. doi:10.1016/S0140-6736(14)60649-8

43. Badalov N, Baradarian R, Iswara K, Li J, Steinberg W, Tenner S. Drug-Induced Acute Pancreatitis:An Evidence-Based Review. Clin Gastroenterol Hepatol 2007;5:648-661. doi:10.1016/j. cgh.2006.11.023

44. Smith W. Adverse drug reactions - allergy? side-effect? intolerance? Aust Fam Physician 2013;42:12-16.

45. Durrington PN, Cairns SA. Acute-pancreatitis: a complication of betablockade. Br Med J (Clin Res Ed) 1982;284:1016.

46. Das S, Ganguly A, Ghosh A, Mondal S, Dey JK, Saha I. Oral pantoprazole-induced acute pancreatitis in an 11-year-old child. Ther Drug Monit 2012;34:242-244. doi:10.1097/FTD.0b013e3182526e6a
47. Murtaza G, Khalid MF, Mungo NA. Recurrent Pantoprazole-Associated Pancreatitis. Am J Ther 2017. doi:10.1097/MJT.0000000000000567

48. Akhtar M, Bhakoo ON, Chandra RK. Pancreatitis in a Child with Leukemia on Intensive Steroid Therapy: Report of a Case. Indian J Pediatr 1964;31:327-329. doi:10.1007/BF02748478

49. Bourne MS, Dawson H. Acute pancreatitis complicating prednisolone therapy. Lancet 1958;2:1209-1210. doi:10.1016/S0140-6736(58)92360-2

50. Campos LM, Omori CH, Lotito AP, Jesus AA, Porta G, Silva CA. Acute pancreatitis in juvenile systemic lupus erythematosus: A manifestation of macrophage activation syndrome? Lupus 2010;19:1654-1658. doi:10.1177/0961203310378863

51. Funayama Y, Fukushima K, Shibata C, et al. Acute pancreatitis complicating ulcerative colitis under administration of corticosteroid in surgical cases. J Gastroenterol 2004;39:592-594. doi:10.1007/s00535004-1350-9

52. Hamed I, Lindeman RD, Czerwinski AW. Case report:acute pancreatitis following corticosteroid and azathioprine therapy. Am J Med Sci 1978;276:211-219.

53. Kolk A, Horneff G, Wilgenbus KK, Wahn V, Gerharz CD. Acute lethal necrotising pancreatitis in childhood systemic lupus erythematosus-possible toxicity of immunosuppressive therapy. Clin Exp Rheumatol 1995;13:399-403.

54. Sabre A, Guthrie MM, Maleknia R. Acute necrotising pancreatitis derived from low-dose corticosteroid use: an important reminder of clinical management. BMJ Case Rep 2015. doi:10.1136/bcr-2015209325

55. Naranjo CA, Busto U, Sellers EM, et al. A method for estimating the probability of adverse drug reactions. Clin Pharmacol Ther 1981;30:239245. doi:10.1038/clpt.1981.154 
Table I. Summary of 5-ASA-induced AP cases

\begin{tabular}{|c|c|c|c|c|c|c|c|c|c|c|c|}
\hline \multicolumn{2}{|r|}{ Author } & \multicolumn{3}{|c|}{ Patient } & \multicolumn{3}{|c|}{ Drug } & \multicolumn{4}{|c|}{ Acute pancreatitis } \\
\hline $\mathrm{Nr}$ & $\begin{array}{c}\text { Name } \\
\text { [reference] }\end{array}$ & Age & Sex & Condition & Active substance & Commercial name & Dose/day & Latency & Resolved & Rechallenge & $\begin{array}{c}\text { Proposed } \\
\text { pathomechanism }\end{array}$ \\
\hline 1 & $\begin{array}{c}\text { Abdullah, } \\
\text { AMA } \\
{[1]}\end{array}$ & 12 & $\mathrm{~m}$ & UC & $\begin{array}{c}\text { Sulfasalazine } \\
\text { Sulfasalazine } \\
\text { 5-ASA e } \\
\text { 5-ASA pH } \\
\text { 5-ASA } \\
\text { 5-ASA T }\end{array}$ & $\begin{array}{l}- \\
- \\
- \\
- \\
- \\
-\end{array}$ & $\begin{array}{c}25-50 \mathrm{mg} / \mathrm{kg} \\
25-50 \mathrm{mg} / \mathrm{kg} \\
2 \mathrm{~g} \\
1.2 \mathrm{~g} \\
1.2 \mathrm{~g} \\
0.5 \mathrm{~g}\end{array}$ & $\begin{array}{c}- \\
2 \text { days } \\
- \\
3 \text { days } \\
1 \text { day } \\
-\end{array}$ & $\begin{array}{c}- \\
2 \text { days } \\
- \\
2 \text { days } \\
- \\
2 \text { days }\end{array}$ & yes & $\begin{array}{l}\text { Idiosyncratic or } \\
\text { hypersensitivity }\end{array}$ \\
\hline 2 & $\begin{array}{c}\text { Adachi, E } \\
\text { [11] }\end{array}$ & 24 & $\mathrm{f}$ & UC & 5-ASA & - & $1.5 \mathrm{~g}-2.25 \mathrm{~g}$ & 9 days & 7 days & no & Hypersensitivity \\
\hline 3 & $\begin{array}{c}\text { Al-Zayani, J } \\
\text { [12] }\end{array}$ & 23 & $\mathrm{f}$ & UC & $\begin{array}{c}\text { 5-ASA pH } \\
\text { Sulfasalazine }\end{array}$ & $\begin{array}{c}\text { Asacol } \\
\text { Azulfidine }\end{array}$ & $\begin{array}{c}1.2 \mathrm{~g}-2.4 \mathrm{~g} \\
3 \mathrm{~g}\end{array}$ & $\begin{array}{l}1 \text { year } \\
9 \text { days }\end{array}$ & $\begin{array}{c}3 \text { days } \\
-\end{array}$ & yes & Dose-related toxic \\
\hline 4 & $\begin{array}{c}\text { Anderson, JR } \\
\text { [13] }\end{array}$ & 39 & $\mathrm{f}$ & UC & $\begin{array}{l}\text { Sulfasalazine } \\
\text { Sulfasalazine } \\
\text { Sulfasalazine } \\
\text { Sulfasalazine } \\
\text { Sulfasalazine }\end{array}$ & $\begin{array}{l}\text { Salazopyrin } \\
\text { Salazopyrin } \\
\text { Salazopyrin } \\
\text { Salazopyrin } \\
\text { Salazopyrin }\end{array}$ & $\begin{array}{l}3 \mathrm{~g} \\
3 \mathrm{~g} \\
3 \mathrm{~g} \\
3 \mathrm{~g} \\
3 \mathrm{~g}\end{array}$ & $\begin{array}{l}- \\
- \\
- \\
- \\
-\end{array}$ & $\begin{array}{l}- \\
- \\
- \\
- \\
-\end{array}$ & yes & - \\
\hline 5 & $\begin{array}{l}\text { Arai, } Y \\
\text { [2] }\end{array}$ & 26 & $\mathrm{~m}$ & UC & $\begin{array}{c}\text { 5-ASA T } \\
\text { Sulfasalazine } \\
\text { 5-ASA pH }\end{array}$ & $\begin{array}{c}\text { Pentasa } \\
\text { Salazosulfapyridine } \\
\text { Asacol }\end{array}$ & $\begin{array}{c}4 \mathrm{~g} \\
- \\
2.4 \mathrm{~g}\end{array}$ & $\begin{array}{l}1 \text { month } \\
\text { Several } \\
\text { weeks } \\
2 \text { weeks }\end{array}$ & $\begin{array}{c}- \\
- \\
4 \text { days }\end{array}$ & yes & Hypersensitivity \\
\hline 6 & $\begin{array}{c}\text { Block, MB } \\
{[14]}\end{array}$ & 29 & $\mathrm{f}$ & RE & $\begin{array}{l}\text { Sulfasalazine } \\
\text { Sulfasalazine } \\
\text { Sulfasalazine } \\
\text { Sulfasalazine }\end{array}$ & $\begin{array}{l}\text { Salicylazosulfapyridine } \\
\text { Salicylazosulfapyridine } \\
\text { Salicylazosulfapyridine } \\
\text { Salicylazosulfapyridine }\end{array}$ & $\begin{array}{l}4 \mathrm{~g} \\
4 \mathrm{~g} \\
- \\
-\end{array}$ & $\begin{array}{c}2 \text { weeks } \\
4 \text { days } \\
\text { - } \\
3 \text { days }\end{array}$ & $\begin{array}{c}- \\
- \\
- \\
7 \text { days }\end{array}$ & yes & Unknown \\
\hline 7 & $\begin{array}{c}\text { Chiba, M } \\
\text { [15] }\end{array}$ & 33 & $\mathrm{~m}$ & UC & $\begin{array}{l}\text { Sulfasalazine } \\
\text { Sulfasalazine } \\
\text { Sulfasalazine }\end{array}$ & $\begin{array}{l}\text { Salazopyrin } \\
\text { Salazopyrin } \\
\text { Salazopyrin }\end{array}$ & $\begin{array}{c}2 \mathrm{~g}-4 \mathrm{~g} \\
3 \mathrm{~g} \\
1 \mathrm{mg}-100 \mathrm{mg}\end{array}$ & $\begin{array}{l}5 \text { weeks } \\
6 \text { days } \\
25 \text { days }\end{array}$ & $\begin{array}{c}3 \text { weeks } \\
7 \text { weeks } \\
\text { - }\end{array}$ & yes & Hypersensitivity \\
\hline 8 & Daniel, F & 41 & $\mathrm{~m}$ & $\mathrm{CD}$ & 5-ASA + 5-ASA e & - & $4 g+1 g$ & 10 days & 3 days & no & - \\
\hline
\end{tabular}




\begin{tabular}{|c|c|c|c|c|c|c|c|c|c|c|c|}
\hline \multicolumn{2}{|r|}{ Author } & \multicolumn{3}{|c|}{ Patient } & \multicolumn{3}{|c|}{ Drug } & \multicolumn{4}{|c|}{ Acute pancreatitis } \\
\hline \multirow[t]{3}{*}{$\mathrm{Nr}$} & $\begin{array}{c}\text { Name } \\
\text { [reference] }\end{array}$ & Age & Sex & Condition & Active substance & Commercial name & Dose/day & Latency & Resolved & Rechallenge & $\begin{array}{c}\text { Proposed } \\
\text { pathomechanism }\end{array}$ \\
\hline & \multirow[t]{2}{*}{ [16] } & 29 & $\mathrm{f}$ & $\mathrm{UC}$ & 5-ASA + 5-ASA e & - & $2 g+1 g$ & 3 days & Few days & no & \multirow{2}{*}{ 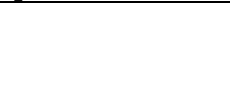 } \\
\hline & & 36 & $\mathrm{f}$ & UC & 5-ASA & - & $3 g$ & 3 weeks & - & no & \\
\hline 9 & $\begin{array}{c}\text { Debongnie, JC } \\
\text { [17] }\end{array}$ & 29 & $\mathrm{f}$ & $\mathrm{CD}$ & $\begin{array}{c}\text { 5-ASA } \\
\text { Sulfasalazine }\end{array}$ & - & $\begin{array}{c}1.5 \mathrm{~g} \\
3 \mathrm{~g}\end{array}$ & $\begin{array}{l}7 \text { weeks } \\
2 \text { weeks }\end{array}$ & $\begin{array}{c}7 \text { days } \\
-\end{array}$ & yes & - \\
\hline 10 & $\begin{array}{c}\text { Deprez, P } \\
{[18]}\end{array}$ & 34 & $\mathrm{~m}$ & $\mathrm{~N} / \mathrm{A}$ & $\begin{array}{l}\text { 5-ASA pH } \\
\text { 5-ASA pH }\end{array}$ & $\begin{array}{l}\text { Claversal } \\
\text { Claversal }\end{array}$ & $\begin{array}{c}1.5 \mathrm{~g} \\
-\end{array}$ & $\begin{array}{l}2 \text { weeks } \\
12 \text { hours }\end{array}$ & $\begin{array}{l}3 \text { days } \\
6 \text { days }\end{array}$ & yes & Unknown \\
\hline 11 & $\begin{array}{c}\text { Din, S } \\
{[37]}\end{array}$ & 31 & $\mathrm{f}$ & $\mathrm{CD}$ & 5-ASA T & Pentasa & - & 4 weeks & 7 days & no & Hypersensitivity \\
\hline 12 & $\begin{array}{c}\text { Erdkamp, F } \\
{[19]}\end{array}$ & 35 & $\mathrm{f}$ & $\mathrm{CD}$ & $\begin{array}{l}\text { 5-ASA pH } \\
\text { 5-ASA pH }\end{array}$ & $\begin{array}{l}\text { Salofalk } \\
\text { Salofalk }\end{array}$ & $\begin{array}{l}1.5 \mathrm{~g} \\
1.5 \mathrm{~g}\end{array}$ & $\begin{array}{l}6 \text { days } \\
2 \text { days }\end{array}$ & $\begin{array}{l}5 \text { days } \\
3 \text { days }\end{array}$ & yes & - \\
\hline 13 & $\begin{array}{c}\text { Eto, } \mathrm{H} \\
{[3]}\end{array}$ & 25 & $\mathrm{f}$ & $\mathrm{UC}$ & $\begin{array}{c}\text { 5-ASA pH } \\
\text { 5-ASA T } \\
\text { 5-ASA }\end{array}$ & $\begin{array}{c}\text { Asacol } \\
\text { Pentasa } \\
\text { - }\end{array}$ & $\begin{array}{l}- \\
- \\
-\end{array}$ & $\begin{array}{c}2 \text { weeks } \\
\text { Several } \\
\text { hours } \\
7 \text { hours }\end{array}$ & $\begin{array}{l}- \\
- \\
-\end{array}$ & yes & - \\
\hline \multirow{2}{*}{14} & \multirow{2}{*}{$\begin{array}{l}\text { Faintuch, J } \\
\text { [20] }\end{array}$} & 37 & $\mathrm{f}$ & UC & Sulfasalazine & - & $2 g-1 g$ & 6 weeks & - & no & \multirow{2}{*}{ Unknown } \\
\hline & & 14 & $\mathrm{f}$ & $\mathrm{CD}$ & Sulfasalazine & - & $1 \mathrm{~g}$ & 5 days & - & no & \\
\hline \multirow{2}{*}{15} & \multirow{2}{*}{$\begin{array}{c}\text { Fernandez, J } \\
\text { [21] }\end{array}$} & 24 & $\mathrm{f}$ & $\mathrm{UC}$ & $\begin{array}{l}\text { 5-ASA } \\
5 \text {-ASA }\end{array}$ & - & $\begin{array}{l}3 g \\
3 g\end{array}$ & $\begin{array}{c}3 \text { months } \\
1 \text { day }\end{array}$ & $\begin{array}{l}5 \text { days } \\
5 \text { days }\end{array}$ & yes & He \\
\hline & & 34 & $\mathrm{~m}$ & UC & $\begin{array}{l}\text { 5-ASA } \\
5 \text {-ASA }\end{array}$ & - & $\begin{array}{c}3 \mathrm{~g} \\
-\end{array}$ & $\begin{array}{c}2 \text { years } \\
12 \text { hours }\end{array}$ & $\begin{array}{l}2 \text { days } \\
20 \text { hours }\end{array}$ & yes & 11уретsensinvity \\
\hline & & 30 & $\mathrm{~m}$ & UC & 5-ASA pH & Asacol & $0.4 \mathrm{~g}-0.8 \mathrm{~g}$ & 5 days & 15 days & no & \\
\hline 16 & $\begin{array}{c}\text { Fiorentini, MT } \\
\text { [22] }\end{array}$ & 19 & $\mathrm{~m}$ & $\mathrm{CD}$ & $\begin{array}{l}\text { 5-ASA pH } \\
\text { 5-ASA pH }\end{array}$ & $\begin{array}{l}\text { Asacol } \\
\text { Asacol }\end{array}$ & $\begin{array}{c}0.4 \mathrm{~g}-1.6 \mathrm{~g} \\
0.4 \mathrm{~g}\end{array}$ & $\begin{array}{l}22 \text { days } \\
14 \text { days }\end{array}$ & - & yes & Hypersensitivity \\
\hline & & 12 & $\mathrm{~m}$ & UC & Olsalazine + 5-ASA e & Dipentum + Rowasa & $1 g+N / A$ & 3 months & 4 days & no & \\
\hline 17 & Garau, P & 13 & $\mathrm{f}$ & UC & Sulfasalazine & - & $1 g-2 g$ & 9 days & 6 days & no & \\
\hline & [23] & 12 & $\mathrm{f}$ & UC & $\begin{array}{c}\text { Sulfasalazine } \\
\text { Olsalazine }\end{array}$ & $\begin{array}{c}- \\
\text { Dipentum }\end{array}$ & $\begin{array}{c}1.5 \mathrm{~g}-1 \mathrm{~g}-2 \mathrm{~g} \\
1 \mathrm{~g}\end{array}$ & $\begin{array}{l}5 \text { months } \\
8 \text { months }\end{array}$ & $\begin{array}{l}6 \text { weeks } \\
1 \text { week }\end{array}$ & yes & \\
\hline 18 & $\begin{array}{c}\text { Inoue, } \mathrm{H} \\
{[24]}\end{array}$ & 40 & $\mathrm{~m}$ & UC & 5-ASA & - & $3 g$ & 4 months & - & no & - \\
\hline 19 & Isaacs, KL & 19 & $\mathrm{f}$ & UC & Sulfasalazine & - & $3 g$ & 3 weeks & - & yes & - \\
\hline
\end{tabular}




\begin{tabular}{|c|c|c|c|c|c|c|c|c|c|c|c|}
\hline \multicolumn{2}{|r|}{ Author } & \multicolumn{3}{|c|}{ Patient } & \multicolumn{3}{|c|}{ Drug } & \multicolumn{4}{|c|}{ Acute pancreatitis } \\
\hline $\mathrm{Nr}$ & $\begin{array}{c}\text { Name } \\
\text { [reference] }\end{array}$ & Age & Sex & Condition & Active substance & Commercial name & Dose/day & Latency & Resolved & Rechallenge & $\begin{array}{c}\text { Proposed } \\
\text { pathomechanism }\end{array}$ \\
\hline & [25] & & & & 5-ASA e & Rowasa & - & 1 week & 3 days & & \\
\hline 20 & $\begin{array}{c}\text { Kutsenko, A } \\
{[4]}\end{array}$ & 63 & $\mathrm{f}$ & UC & $\begin{array}{c}\text { 5-ASA pH } \\
\text { 5-ASA pH+ 5-ASA e }\end{array}$ & $\begin{array}{c}\text { Lialda } \\
\text { Asacol + - }\end{array}$ & - & $\begin{array}{c}2 \text { years } \\
-\end{array}$ & - & yes & - \\
\hline 21 & $\begin{array}{c}\text { Manfredini, R } \\
{[26]} \\
\end{array}$ & 29 & $\mathrm{f}$ & $\mathrm{AC}$ & 5-ASA & - & $0.8 \mathrm{~g}$ & 2 days & 5 days & no & - \\
\hline 22 & $\begin{array}{c}\text { Niu, G } \\
{[27]}\end{array}$ & 28 & $\mathrm{f}$ & UC & Sulfasalazine & - & $6 \mathrm{~g}$ & 70 days & - & no & - \\
\hline 23 & $\begin{array}{c}\text { Ouakaa- } \\
\text { Kchaou, A } \\
{[28]} \\
\end{array}$ & 33 & $\mathrm{~m}$ & UC & 5-ASA & - & $2 g-4 g$ & $\begin{array}{c}18 \\
\text { months }\end{array}$ & - & no & - \\
\hline 24 & $\begin{array}{c}\text { Paerregaard, A } \\
{[29]}\end{array}$ & 7 & $\mathrm{f}$ & UC & $\begin{array}{l}\text { 5-ASA T } \\
\text { 5-ASA e }\end{array}$ & $\begin{array}{l}\text { Pentasa } \\
\text { Pentasa }\end{array}$ & $\begin{array}{c}1.5 \mathrm{~g}-2.25 \mathrm{~g} \\
1 \mathrm{~g}\end{array}$ & $\begin{array}{l}7 \text { months } \\
2 \text { weeks }\end{array}$ & 2 days & yes & $\begin{array}{l}\text { Idiosyncratic or } \\
\text { hypersensitivity }\end{array}$ \\
\hline 25 & $\begin{array}{c}\text { Paul, AC } \\
{[5]}\end{array}$ & 10 & $\mathrm{~m}$ & UC & 5-ASA pH & Mesacol & $0.8 \mathrm{~g}-1.6 \mathrm{~g}$ & 5 months & 3 days & no & Hypersensitivity \\
\hline 26 & $\begin{array}{c}\text { Poldermans, D } \\
{[30]}\end{array}$ & 24 & $\mathrm{f}$ & $\mathrm{CD}$ & $\begin{array}{c}\text { Sulfasalazine } \\
\text { Olsalazine } \\
\text { Olsalazine } \\
\end{array}$ & $\begin{array}{c}\text { Salicylazosulfapyridine } \\
\text { Dipentum } \\
\text { Dipentum }\end{array}$ & $\begin{array}{r}4 \mathrm{~g} \\
1.5 \mathrm{~g} \\
1.5 \mathrm{~g} \\
\end{array}$ & $\begin{array}{c}7 \text { days } \\
5 \text { days } \\
30 \text { hours } \\
\end{array}$ & $\begin{array}{c}- \\
7 \text { days } \\
2 \text { days } \\
\end{array}$ & yes & Hypersensitivity \\
\hline 27 & $\begin{array}{c}\text { Radke, } M \\
\text { [31] }\end{array}$ & 12 & $\mathrm{~m}$ & $\mathrm{CD}$ & $\begin{array}{c}\text { Sulfasalazine } \\
\text { 5-ASA pH } \\
\text { 5-ASA e }\end{array}$ & $\begin{array}{c}- \\
\text { Salofalk } \\
\text { Salofalk }\end{array}$ & $\begin{array}{c}2 \mathrm{~g} \\
1.5 \mathrm{~g} \\
4 \mathrm{~g}\end{array}$ & $\begin{array}{l}2 \text { weeks } \\
1 \text { week } \\
1 \text { week }\end{array}$ & $\begin{array}{c}- \\
- \\
7 \text { days }\end{array}$ & yes & - \\
\hline 28 & $\begin{array}{c}\text { Rubin, } \mathrm{R} \\
{[32]}\end{array}$ & 37 & $\mathrm{~m}$ & UC & Sulfasalazine & Azulfidine & $4 \mathrm{~g}$ & 2 weeks & - & no & Hypersensitivity \\
\hline 29 & $\begin{array}{l}\text { Sachedina, B } \\
\text { [33] }\end{array}$ & 32 & $\mathrm{f}$ & $\mathrm{CD}$ & $\begin{array}{l}\text { 5-ASA pH } \\
\text { 5-ASA pH } \\
\text { 5-ASA pH }\end{array}$ & $\begin{array}{l}\text { Asacol } \\
\text { Asacol } \\
\text { Asacol }\end{array}$ & $\begin{array}{l}2.4 \mathrm{~g} \\
1.2 \mathrm{~g} \\
1.2 \mathrm{~g}\end{array}$ & $\begin{array}{l}2 \text { days } \\
2 \text { days } \\
2 \text { days }\end{array}$ & $\begin{array}{l}3 \text { days } \\
2 \text { days } \\
2 \text { days }\end{array}$ & yes & Unknown \\
\hline 30 & $\begin{array}{c}\text { Suryapranata, } \\
\text { H } \\
{[34]} \\
\end{array}$ & 22 & $\mathrm{f}$ & N/A & $\begin{array}{l}\text { Sulfasalazine } \\
\text { Sulfasalazine }\end{array}$ & - & $\begin{array}{c}2 \mathrm{~g} \\
-\end{array}$ & $\begin{array}{c}- \\
1 \text { day }\end{array}$ & $\begin{array}{l}12 \text { days } \\
2 \text { days } \\
\end{array}$ & yes & - \\
\hline 31 & $\begin{array}{c}\text { Tanigawara, } \mathrm{Y} \\
{[38]}\end{array}$ & 43 & $\mathrm{~m}$ & UC & $\begin{array}{l}\text { Sulfasalazine } \\
\text { Sulfasalazine }\end{array}$ & $\begin{array}{l}\text { Salazopirin } \\
\text { Salazopirin }\end{array}$ & $\begin{array}{c}4 \mathrm{~g} \\
0.5 \mathrm{~g}\end{array}$ & $\begin{array}{l}6 \text { days } \\
6 \text { days }\end{array}$ & $\begin{array}{l}9 \text { days } \\
1 \text { days }\end{array}$ & yes & - \\
\hline 32 & $\begin{array}{c}\text { Toubanakis, C } \\
{[35]}\end{array}$ & 19 & $\mathrm{~m}$ & UC & $\begin{array}{l}\text { 5-ASA } \\
\text { 5-ASA }\end{array}$ & - & $\begin{array}{c}2.4 \mathrm{~g}-1.2 \mathrm{~g} \\
1.2 \mathrm{~g}\end{array}$ & $\begin{array}{l}1 \text { year } \\
1 \text { day }\end{array}$ & $\begin{array}{l}5 \text { days } \\
4 \text { days }\end{array}$ & yes & Hypersensitivity \\
\hline
\end{tabular}




\begin{tabular}{|c|c|c|c|c|c|c|c|c|c|c|c|}
\hline \multicolumn{2}{|r|}{ Author } & \multicolumn{3}{|c|}{ Patient } & \multicolumn{3}{|c|}{ Drug } & \multicolumn{4}{|c|}{ Acute pancreatitis } \\
\hline $\mathrm{Nr}$ & $\begin{array}{c}\text { Name } \\
\text { [reference] }\end{array}$ & Age & Sex & Condition & Active substance & Commercial name & Dose/day & Latency & Resolved & Rechallenge & $\begin{array}{c}\text { Proposed } \\
\text { pathomechanism }\end{array}$ \\
\hline 33 & $\begin{array}{c}\text { Tran, K } \\
{[36]}\end{array}$ & 18 & $\mathrm{~m}$ & $\mathrm{UC}$ & 5-ASA + 5-ASA e & - & $4 g+1 g$ & 17 days & 3 days & no & - \\
\hline 34 & $\begin{array}{c}\text { Uribarri- } \\
\text { Gonzalez, L } \\
{[39]} \\
\end{array}$ & 35 & $\mathrm{~m}$ & UC & $\begin{array}{c}\text { 5-ASA pH } \\
\text { 5-ASA e } \\
\end{array}$ & $\begin{array}{c}\text { Claversal } \\
- \\
\end{array}$ & $\begin{array}{c}\mathrm{g} \\
- \\
\end{array}$ & $\begin{array}{l}2 \text { years } \\
2 \text { weeks }\end{array}$ & - & yes & - \\
\hline 35 & $\begin{array}{c}\text { Wada, S } \\
\text { [40] }\end{array}$ & 13 & $\mathrm{~m}$ & $\mathrm{UC}$ & $\begin{array}{l}\text { 5-ASA } \\
\text { 5-ASA }\end{array}$ & $\begin{array}{l}- \\
-\end{array}$ & $\begin{array}{c}3 \mathrm{~g} \\
-\end{array}$ & $\begin{array}{c}- \\
1 \text { day }\end{array}$ & - & yes & Hypersensitivity \\
\hline 36 & Our case & 31 & $\mathrm{f}$ & $\mathrm{CD}$ & $\begin{array}{l}\text { 5-ASA T } \\
\text { 5-ASA T }\end{array}$ & $\begin{array}{l}\text { Pentasa } \\
\text { Pentasa }\end{array}$ & $\begin{array}{c}2 g-4 g \\
4 g\end{array}$ & $\begin{array}{l}6 \text { weeks } \\
8 \text { hours }\end{array}$ & $\begin{array}{l}4 \text { days } \\
3 \text { days }\end{array}$ & yes & Idiosyncratic \\
\hline
\end{tabular}

$\mathrm{UC}=$ ulcerative colitis, $\mathrm{CD}=$ Crohn's disease, $\mathrm{RE}=$ regional enteritis, $\mathrm{AC}=$ aspecific colitis, 5 -ASA e = enema formulation,

5-ASA $\mathrm{pH}=\mathrm{pH}$ dependent acrylic coated formulation, 5-ASA $\mathrm{T}=$ time dependent ethyl-cellulose coated formulation,

Resolve of AP: time of symptomatic improvement and/or enzyme level normalization. 